\title{
Effects of nickel hyperaccumulation in Alyssum pintodasilvae on model arthropods representatives of two trophic levels
}

\author{
M. Teresa Gonçalves • Susana C. Gonçalves • \\ António Portugal · Sandra Silva • \\ José Paulo Sousa $\cdot$ Helena Freitas
}

Received: 14 October 2006/ Accepted: 25 November 2006/Published online: 30 December 2006

(C) Springer Science+Business Media B.V. 2006

\begin{abstract}
An experimental assessment of the defence hypothesis of nickel $(\mathrm{Ni})$ hyperaccumulation in Alyssum was lacking. Also, to date no study had investigated the effects of hyperaccumulator litter on a detritivore species. We performed several experiments with model arthropods representatives of two trophic levels: Tribolium castaneum (herbivore) and Porcellio dilatatus (detritivore). In no-choice trials using artificial food disks with different $\mathrm{Ni}$ concentrations, T. castaneum fed significantly less as Ni concentration increased and totally rejected disks with the highest $\mathrm{Ni}$ concentration. In choice tests, insects preferred disks without $\mathrm{Ni}$. In the no-choice experiment, mortality was low and did not differ significantly among treatments. Hence, this suggested a deterrent effect of high Ni diet. Experi-
\end{abstract}

M. T. Gonçalves $(\bowtie) \cdot$ A. Portugal Instituto do Ambiente e Vida, Departamento de Botânica, Universidade de Coimbra, Calçada Martim de Freitas, Coimbra 3001-455, Portugal e-mail: mtgoncal@bot.uc.pt

S. C. Gonçalves · S. Silva · H. Freitas

Departamento de Botânica, Universidade de

Coimbra, Calçada Martim de Freitas,

Coimbra 3001-455, Portugal

J. P. Sousa

Instituto do Ambiente e Vida, Departamento de Zoologia, Universidade de Coimbra, Largo Marquês de Pombal, 3004-517 Coimbra, Portugal ments with $P$. dilatatus showed that isopods fed $A$. pintodasilvae litter showed significantly greater mortality $(83 \%)$ than isopods fed litter from the non-hyperaccumulator species Iberis procumbens (8\%), Micromeria juliana (no mortality) or Alnus glutinosa (no mortality). Also, isopods consumed significantly greater amounts of litter from the nonhyperaccumulator plant species. The behaviour of isopods fed $A$. pintodasilvae litter suggested an antifeedant effect of $\mathrm{Ni}$, possibly due to postingestive toxic effects. Our results support the view that Ni defends the Portuguese serpentine hyperaccumulator $A$. pintodasilvae against herbivores, indicating that $\mathrm{Ni}$ can account both for feeding deterrence and toxic effects. The effects of hyperaccumulator litter on the detritivore $P$. dilatatus suggest that the activity of these important organisms may be significantly impaired with potential consequences on the decomposition processes.

Keywords Alyssum pintodasilvae - Defence hypothesis - Deterrence of herbivory vs. acute toxicity · Nickel hyperaccumulation · Porcellio dilatatus . Tribolium castaneum - Serpentine

\section{Introduction}

Metal hyperaccumulation in plants is a rare but well recognized phenomenon that can be observed essentially in metalliferous soils. It is 
defined as the ability of plants to accumulate exceptionally high concentrations of metals in their shoots without exhibiting symptoms of metal toxicity (Brooks et al. 1977). The threshold concentrations used to define hyperaccumulation depend on the element involved: $100 \mu \mathrm{g} \mathrm{g}^{-1} \mathrm{dry}$ weight for $\mathrm{Cd}, \mathrm{Co}, \mathrm{Cr}$ and $\mathrm{Pb}, 1,000 \mu \mathrm{g} \mathrm{g}^{-1}$ dry weight for $\mathrm{Ni}, \mathrm{Cu}$ and $\mathrm{Se}$, and $10,000 \mu \mathrm{g} \mathrm{g}^{-1}$ dry weight for $\mathrm{Zn}$ and Mn (Reeves and Baker 2000). The great majority of hyperaccumulator plant species are Ni hyperaccumulators from serpentine soils, and Alyssum is the plant genus with more $\mathrm{Ni}$ hyperaccumulator species (Reeves and Baker 2000).

The hyperaccumulation trait has been hypothesized to perform several ecological functions in hyperaccumulator plants. The proposed hypotheses include metal tolerance/disposal, interference with other plants (elemental allelopathy), drought resistance and defence against some herbivores and pathogens (Boyd and Martens 1992; Boyd and Martens 1998). In recent years, the so-called defence hypothesis has been thoroughly investigated. Although some studies showed no defensive effects of high levels of $\mathrm{Zn}$ (Huitson and Macnair 2003; Noret et al. 2005), a growing body of experimental evidence exists indicating that hyperaccumulation may defend plants against herbivores (Boyd and Martens 1994; Martens and Boyd 1994; Pollard and Baker 1997; Jhee et al. 1999; Boyd et al. 2002; Hanson et al. 2003; Behmer et al. 2005; Jiang et al. 2005; Jhee et al. 2006) as well as against pathogens (Boyd et al. 1994; Ghaderian et al. 2000; Hanson et al. 2003). Defence can be achieved by two known mechanisms. One is by acute toxicity of high metal-containing plant tissue, in which ingestion results in mortality (Boyd and Martens 1994; Martens and Boyd 1994). A different mechanism is via deterrence of herbivory. In this case, if a choice is provided, high-metal containing material is ingested in lesser extent than lowmetal containing tissue (Jhee et al. 1999; Jiang et al. 2005). Feeding deterrence is particularly beneficial for plant fitness because it reduces feeding damage (Boyd and Jhee 2005). Nevertheless, though reported, total feeding avoidance is rare (Pollard and Baker 1997). In most cases, the two mechanisms combine and aversion to high metal containing plant tissue develops postingestively (Hanson et al. 2004; Behmer et al. 2005).

Alyssum pintodasilvae Dudley (syn. A. serpyllipholium Desf. subsp. lusitanicum Dudley and Pinto da Silva) (cf. Dudley 1986) is a perennial Brassicaceae endemic to serpentine soils in NE Portugal (Pinto da Silva 1970; Menezes de Sequeira and Pinto da Silva 1992). This Ni hyperaccumulator reaches more than $50 \%$ cover in some locations and has been shown to contribute to the flux of $\mathrm{Ni}$ to herbivore and carnivore trophic levels in these areas (Peterson et al. 2003).

The ecological function and evolutionary value of Ni hyperaccumulation in the genus Alyssum has already received some attention. Several hypotheses have been investigated, for instance, increased drought resistance (Whiting et al. 2003) or elemental allelopathy (Zhang et al. 2005) but experimental support was not found for neither. In contrast, Ghaderian et al. (2000) found that $\mathrm{Ni}$ hyperaccumulation in $A$. pintodasilvae and $A$. murale protects the plants from the pathogenic fungus Pythium. So far, to our knowledge, the protective role of $\mathrm{Ni}$ hyperaccumulation against herbivores has not been tested in Alyssum.

Terrestrial isopods play an important role in the early stages of the decomposition processes. Mainly feeding on conditioned leaves, their activity enhances litter fragmentation, increasing the area for fungal and bacterial attack and, therefore, promoting microbial degradation (Van Wensem et al. 1993; Szlávecz and Pobozsny 1995). Surprisingly, however, as Boyd (2004) has pointed out, the influence of hyperaccumulator litter on decomposer communities is as yet virtually unexplored. This is even more unexpected since Boyd and Martens (1998) had already suggested that decomposers are likely to face the same toxicity problems as herbivores and/or pathogens.

In this study we used two model arthropods: the insect Tribolium castaneum (Insecta: Coleoptera) and the terrestrial isopod Porcellio dilatatus (Crustacea: Isopoda) as experimental animals. $T$. castaneum is a common pest feeding on cereals and cereal products. This species is widely used as a model insect in laboratory trials, particularly in chemical ecology (e.g. Alonso-Amelot et al. 
1994). P. dilatatus is an important member of the macroarthropod communities inhabiting the upper layer of the soil and surface leaf litter, common in southern Europe terrestrial ecosystems. Moreover, $P$. dilatatus has been investigated in ecotoxicology (Ribeiro et al. 1999; Ribeiro et al. 2001). Because they are well-characterized organisms, further investigation about the mechanisms of toxicity/tolerance is possible. Both animals are easy to maintain in laboratory conditions. Our specific objectives were: (i) to test the defence hypothesis of $\mathrm{Ni}$ hyperaccumulation in $A$. pintodasilvae, including deterrence $v$ s toxicity on $T$. castaneum, and (ii) to investigate the effect of $A$. pintodasilvae litter on $P$. dilatatus.

\section{Materials and methods}

Study organisms: plants and animals

Leaves of Alyssum pintodasilvae were collected in Alimonde (UTM 29TPG2975), a serpentine outcrop in NE Portugal, in June and September 2004. Samples of individual plants $(n=6$ in June and $n=3$ in September) and a composite sample (collected in June) were used to determine leaf $\mathrm{Ni}$ concentrations. The composite sample was used in the experiment with Tribolium castaneum (experiment 1) and leaves collected in September were used in the experiment with Porcellio dilatatus (experiment 4). Air dried leaf material was ground with liquid nitrogen. Weighed subsamples were digested in $2 \mathrm{ml}$ of concentrated nitric acid $(69 \% \mathrm{v} / \mathrm{v})$, in closed Teflon vessels, during $8 \mathrm{~h}$ at $150^{\circ} \mathrm{C}$. After appropriate dilutions, $\mathrm{Ni}$ was measured in the clear samples by flame atomic absorption spectrophotometry (Perkin Elmer Aanalyst 100).

Leaves from Alnus glutinosa (alder), Iberis procumbens and Micromeria juliana were collected in non-serpentine areas in September 2005 and used in the experiment with $P$. dilatatus. Alder (Betulaceae) was chosen as positive control as it is a food preferred by isopods, inducing high growth rates and reproductive performance in specimens in laboratory cultures (Caseiro et al. 2000). I. procumbens, a non-hyperaccumulator perennial Brassicaceae, was selected because non-hyperaccumulator perennial Alyssum species were not available at the time. M. juliana (Lamiaceae) was used because of its small leaves and texture similar to $A$. pintodasilvae, allowing an evaluation of possible feeding inhibition due to morphological traits. Ni concentrations were also determined in leaf samples of these species to confirm their non-hyperaccumulator status.

The specimens of $T$. castaneum and of $P$. dilatatus used in the experiments were obtained from laboratory populations kept at the Department of Zoology, University of Coimbra. T. castaneum were maintained on a wheat flour diet (Ó Ceallacháin and Ryan 1977) and kept at room temperature in the dark. $P$. dilatatus were fed alder leaves and kept at $22^{\circ} \mathrm{C}$ and $16 \mathrm{~h}: 8 \mathrm{~h}$ (light:dark) photoperiod.

\section{Experimental setup}

Four experiments were conducted: $T$. castaneum fed wheat flour diet amended with $A$. pintodasilvae leaves (experiment 1 ); $T$. castaneum fed synthetic diet disks amended with $\mathrm{Ni}$, including a no-choice (experiment 2) and a choice experiment (experiment 3 ) and $P$. dilatatus fed A. pintodasilvae litter and litter of $\mathrm{Ni}$ nonhyperaccumulator plant species: A. glutinosa, I. procumbens and M. juliana (experiment 4).

Experiment 1: $T$. castaneum fed flour diet amended with $A$. pintodasilvae leaves

This experiment was designed to evaluate the behaviour of $T$. castaneum fed $A$. pintodasilvae leaves. Since $T$. castaneum feed on cereal products, wheat flour diet (Ó Ceallacháin and Ryan 1977) was amended with $A$. pintodasilvae powdered leaves to different percentages: 2, 5 and $10 \%(w / w)$. From these amendments we could infer the following $\mathrm{Ni}$ concentrations: 200, 500 and $1,000 \mu \mathrm{g} \mathrm{g}^{-1}$, respectively. Diet not amended with leaves was used as control. The experiment was conducted in Petri plates $(9 \mathrm{~cm} \varnothing)$ each with $20 \mathrm{~g}$ of flour diet. Insects were submitted to starvation for $24 \mathrm{~h}$ before the experiment and then randomly assigned to Petri plates until 20 individuals were in each plate. There were five replicates per treatment. Insects were maintained 
at room temperature, in the dark, for 26 days. During this period, larvae and dead insects were removed and counted weekly. Insects were weighed at the beginning and at the end of the experiment to assess biomass change.

Experiments 2 and 3: T. castaneum fed synthetic diet disks amended with $\mathrm{Ni}$

Experiments 2 and 3 were designed to evaluate the effects of $\mathrm{Ni}$ addition to artificial diet disks offered to $T$. castaneum (no-choice and choice experiments). Diet disks were prepared according to Alonso-Amelot et al. (1994). Ni was added as $\mathrm{NiSO}_{4} \cdot 6 \mathrm{H}_{2} \mathrm{O}$ to diet disks (each $8 \mathrm{~mm} \varnothing, c a$. $40 \mathrm{mg}$ ) in order to obtain the following $\mathrm{Ni}$ treatments (w/w, in the disks): control (no added $\mathrm{Ni})$, low $\left(5,000 \mu \mathrm{g} \mathrm{g}^{-1} \mathrm{Ni}\right)$, intermediate $\left(13,000 \mu \mathrm{g} \mathrm{g}^{-1} \mathrm{Ni}\right)$ and high $\left(25,000 \mu \mathrm{g} \mathrm{g}^{-1} \mathrm{Ni}\right)$. Before the experiments, recently emerged adults of $T$. castaneum were exposed to unamended diet disks for $48 \mathrm{~h}$ for conditioning. After this period, insects were starved for $48 \mathrm{~h}$ before the beginning of the experiments. The experiments were conducted in Petri plates $(9 \mathrm{~cm} \varnothing)$ lined with filter paper. On both experiments, insects were maintained at room temperature, in the dark, for $96 \mathrm{~h}$.

\section{No-choice experiment}

Ten adult insects and one diet disk were put in each Petri plate. Four treatments, corresponding to the four $\mathrm{Ni}$ concentrations, were assayed with four replicates per treatment. Insects were weighed after the starvation period and at the end of the $96 \mathrm{~h}$ experimental period to assess biomass change; food consumption was assessed by weight change of the disks. Mortality was registered at the end of the trial.

\section{Choice experiment}

In this experiment, designed to examine insect feeding preference, $T$. castaneum were given the choice between control disks and $\mathrm{Ni}$ amended disks, in the following combinations: (control $\left.+5,000 \mu \mathrm{g} \mathrm{g}^{-1} \mathrm{Ni}\right), \quad\left(\right.$ control $+13,000 \mu \mathrm{g} \mathrm{g}^{-1}$ $\mathrm{Ni}$ ) and (control $+25,000 \mu \mathrm{g} \mathrm{g}^{-1} \mathrm{Ni}$ ). Ten adult insects and a pair of disks were put in each Petri plate, with four replicates per treatment. Food consumption was assessed by weight change of the disks.

\section{Experiment 4: $P$. dilatatus fed A. pintodasilvae} and non-hyperaccumulator species

This experiment aimed to compare the behaviour of the detritivore $P$. dilatatus fed litter of a $\mathrm{Ni}$ hyperaccumulator (A. pintodasilvae) and of nonhyperaccumulator species. All leaf types (Alyssum pintodasilvae, Alnus glutinosa, Iberis procumbens and Micromeria juliana) were collected prior to abscission, air dried, and stored until used. Before starting the experiment, leaves were placed in litter bags and conditioned naturally in the understorey of the Coimbra Botanical Garden for 1 month (except alder leaves that stayed there only for 15 days). After that period, the litter bags were kept at $4^{\circ} \mathrm{C}$ until used. The experiment was conducted in small lidded plastic boxes covered on the bottom with a layer of Plaster of Paris each with $100 \mathrm{mg}$ of litter material and one isopod. Specimens of $P$. dilatatus of known weight were distributed randomly among the four leaf types; twelve replicates per treatment were performed. Isopods were maintained at $25^{\circ} \mathrm{C}$ and $16 \mathrm{~h}: 8 \mathrm{~h}$ (light:dark) photoperiod, for 30 days. During this period, moist conditions were guaranteed by regular spraying with water and new food offered when necessary. Mortality was registered on days 8, 15, 23 and 30. Faeces and dead isopods were removed on the same days. At the end of the experiment, the remaining leaves, isopods and the total amount of faeces were weighed. Consumption rate was expressed as litter consumption per animal biomass per week. Growth efficiency was determined as the ratio between isopod biomass change and assimilation at the end of the experiment; assimilation was calculated as the difference between food consumption and faeces produced. Since phenolics content can greatly influence leaf palability to isopods (Sousa et al. 1998), the total phenolics were determined in conditioned leaves according to a modified FolinDenis method (Swain and Hillis 1959). Phenolics were extracted with $50 \%$ acetone and measured colorimetrically in a JENWAY 6100 spectrophotometer. 
Statistical analysis

In all experiments, except experiment 3 , differences between treatments were evaluated using one-way ANOVA followed by a Tukey multiple comparison test. Normality and homocedasticity were verified by Kolmogorov-Smirnov and Levene tests, respectively (Zar 1996). When ANOVA assumptions were not met, data were either arcsin or log transformed according to Zar (1996). When assumptions were not met even after data transformation (mortality data in experiment 4), data were analysed by a Kruskal-Wallis test followed by a Dunn post-hoc test. In the choice experiment (experiment 3), food consumption in disks of each combination was analysed using paired $t$-tests, since the level of consumption of one disk depended on the palatability of the other. A significance level of $P<0.05$ was always selected. All the analyses were performed using SPSS statistical package 14.0 (SPSS 2005).

\section{Results}

Ni concentrations in A. pintodasilvae

Mean Ni concentration in Alyssum pintodasilvae leaves collected in June $(n=6)$ was $7,100 \mu \mathrm{g} \mathrm{g}^{-1}$ of leaf dry mass, ranging from 5,100 to $8,800 \mu \mathrm{g} \mathrm{g}^{-1}$. The Ni concentration in the composite sample used in the experiment with Tribolium castaneum (experiment 1) was $9,900 \mu \mathrm{g} \mathrm{g}^{-1}$. Mean Ni concentration in $A$. pintodasilvae leaves collected in September $(n=3)$ and used in the experiment with Porcellio dilatatus (experiment 4) was $11,100 \mu \mathrm{g} \mathrm{g}^{-1}$ of leaf dry mass, ranging from 10,700 to $11,400 \mu \mathrm{g} \mathrm{g}^{-1}$. Values were in general agreement with published results for $A$. pintodasilvae (Brooks and Radford 1978; Menezes de Sequeira and Pinto da Silva 1992; Peterson et al. 2003).

Experiment 1: $T$. castaneum fed flour diet amended with $A$. pintodasilvae leaves

The addition of $A$. pintodasilvae leaves to the wheat flour diet did not significantly influence the mortality $\left(F_{3,16}=1.60, P=0.23\right.$; Fig. $\left.1 \mathrm{a}\right)$ nor the reproductive output $\left(F_{3,16}=2.99, P=0.06\right.$; Fig. $1 \mathrm{~b}$ ) of $T$. castaneum. Also, biomass change did not differ significantly among the different treatments $\left(F_{3,16}=1.64, P=0.22\right.$; Fig. $\left.1 \mathrm{c}\right)$. Nonetheless, a trend in biomass response could be detected: after a hormetic effect at $2 \%$ leaf
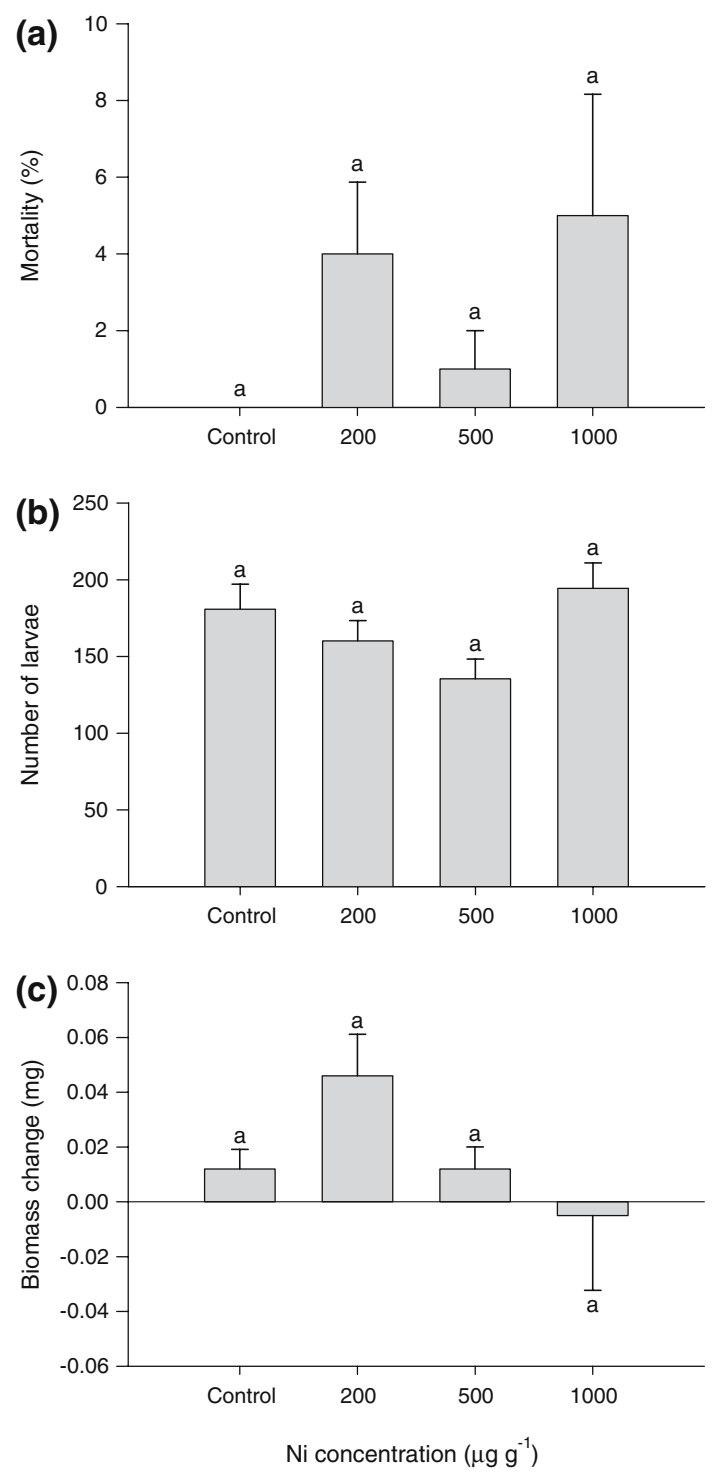

Fig. 1 (a) Mortality, (b) Reproductive output and (c) Biomass change of Tribolium castaneum kept for 26 days on flour diet amended with Alyssum pintodasilvae powdered leaves, corresponding to 200, 500 and $1000 \mu \mathrm{g} \mathrm{g}^{-1}$ Ni. Diet not amended with leaves was used as control. Results are means \pm SE of five replicates per treatment with 20 insects per replicate. Same letter indicates no significant differences by one-way ANOVA $(P \geq 0.05)$ 
amendment (inducing an increase in weight in comparison to control) the weight gain decreased with increasing percentage of $A$. pintodasilvae leaves, with the $10 \%$ leaf amendment inducing a biomass loss (Fig. 1c). To check if Ni could cause a feeding inhibition it was decided to conduct experiments with synthetic diet disks amended with $\mathrm{Ni}$.

\section{Experiment 2: no-choice experiment}

In the no-choice experiment, food consumption decreased significantly $\left(F_{3,16}=14 P<0.001\right)$ as the Ni concentration of diet disks increased, with no consumption in the highest $\mathrm{Ni}$ treatment (Fig. 2a). Insects lost weight in all treatments (Fig. 2b) but increasing Ni concentration induced
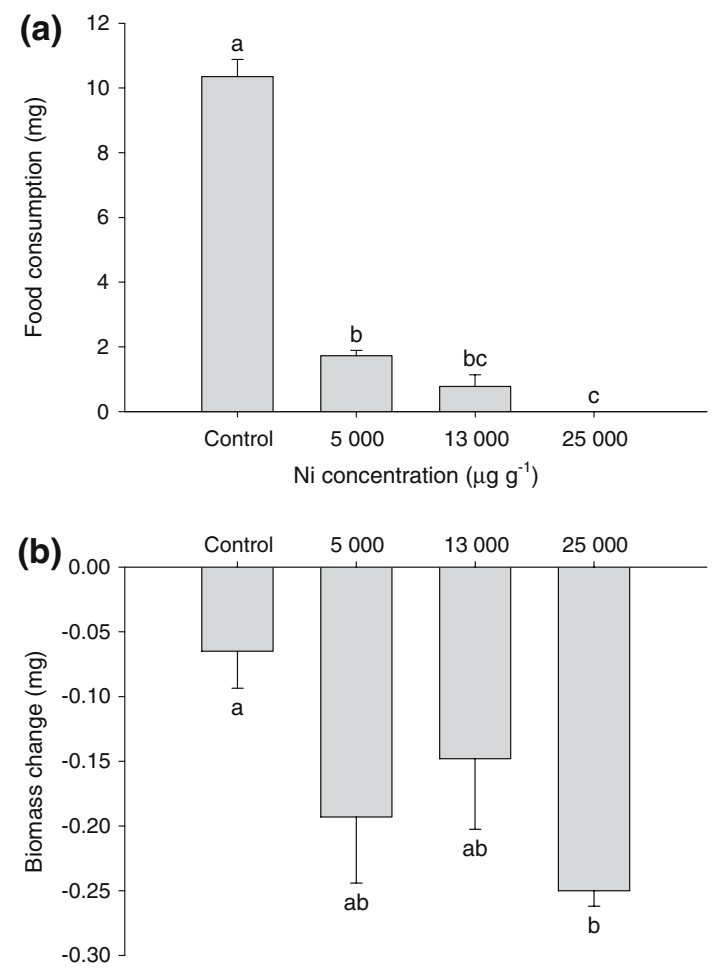

Fig. 2 (a) Food consumption and (b) Biomass change of Tribolium castaneum in a no-choice experiment, after $96 \mathrm{~h}$. In each treatment insects were offered a single diet disk with different $\mathrm{Ni}$ concentrations: control (no added $\mathrm{Ni}$ ), 5,000, 13,000, and $25,000 \mu \mathrm{g} \mathrm{g}^{-1} \mathrm{Ni}$. Values are means \pm SE of four replicates per treatment with 10 insects per replicate. Different letters indicate significant differences at $P<0.05$ according to Tukey's post-hoc test progressively greater biomass losses $\left(F_{3,16}=3.75\right.$, $P<0.05$; Fig. 2b). In the control treatment (no added $\mathrm{Ni}$ ) insects also lost weight, in spite of the high food consumption. This may be attributed to the $48 \mathrm{~h}$ starvation period before the beginning of the experiment. Mortality was low and did not differ significantly between treatments $\left(F_{3,16}=1.44, P=0.28\right)$, probably due to the short period of the experiment (96 h).

\section{Experiment 3: choice experiment}

Results showed insects preferred control disks, as indicated by greater consumption of control disks in all tested combinations (Figs. 3, 4). In one replicate from the combination (control $+13,000 \mu \mathrm{g} \mathrm{g}^{-1} \mathrm{Ni}$ ), insects did not discriminate between disks, resulting in the marginally non-significant difference $(P=0.06)$ for this combination. In the combination (control $+25,000 \mu \mathrm{g} \mathrm{g}^{-1} \mathrm{Ni}$ ) no detectable consumption of $\mathrm{Ni}$ amended disks was observed (Figs. 3, 4).

Experiment 4: $P$. dilatatus fed litter of A. pintodasilvae and of non-hyperaccumulator species

$\mathrm{Ni}$ concentrations in $A$. pintodasilvae leaves were determined in dried samples before and after leaf conditioning. Mean concentrations were $11,100 \pm 200$ and $13,500 \pm 600 \mu \mathrm{g} \mathrm{g}^{-1} \mathrm{Ni}$ (mean $\pm \mathrm{SE}$ ), before and after conditioning, respectively $\left(t_{(1), 4}=-3.77, P<0.01\right)$. Ni concentrations in leaves of the other plant species were in the normal range $\left(\leq 10 \mu \mathrm{g} \mathrm{g}^{-1}\right)$ (Reeves and Baker 2000). No significant differences in total phenolics were detected among plant species $\left(F_{3,8}=2.92, \quad P=0.10\right)$. Concentrations were $1.46 \pm 0.11, \quad 1.61 \pm 0.06, \quad 1.95 \pm 0.21$ and $1.83 \pm$ $0.06 \mathrm{mg} \mathrm{g}^{-1} \quad$ (mean $\pm \mathrm{SE}$ ) for $A$. pintodasilvae, Iberis procumbens, Micromeria juliana and Alnus glutinosa, respectively.

Mortality was significantly greater in isopods fed A. pintodasilvae litter than in isopods fed litter from the other three plant species $\left(H_{3,44}=32.7, P<0.001\right.$; Fig. 5). At the end of 


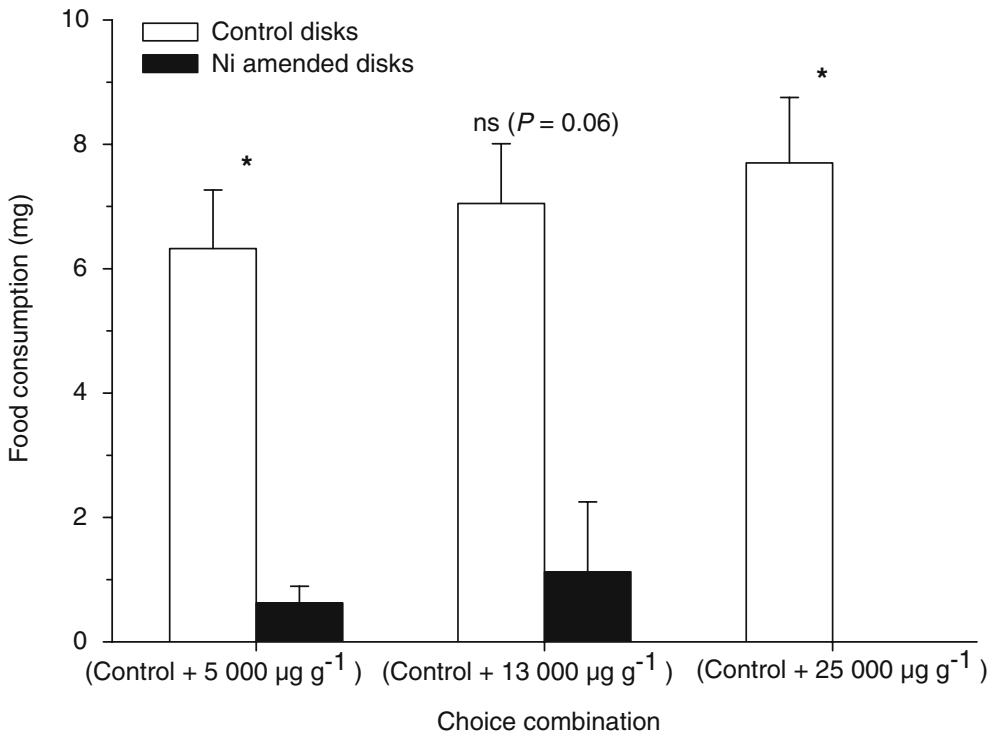

Fig. 3 Food consumption by Tribolium castaneum when offered a choice between $\mathrm{Ni}$ amended and unamended (control) diet disks after $96 \mathrm{~h}$. Three choice combinations were tested: (control $\left.+5,000 \mu \mathrm{g} \mathrm{g}^{-1} \mathrm{Ni}\right)$, (control + $\left.13,000 \mu \mathrm{g} \mathrm{g}^{-1} \mathrm{Ni}\right)$ and (control $\left.+25,000 \mu \mathrm{g} \mathrm{g}^{-1} \mathrm{Ni}\right)$. Values
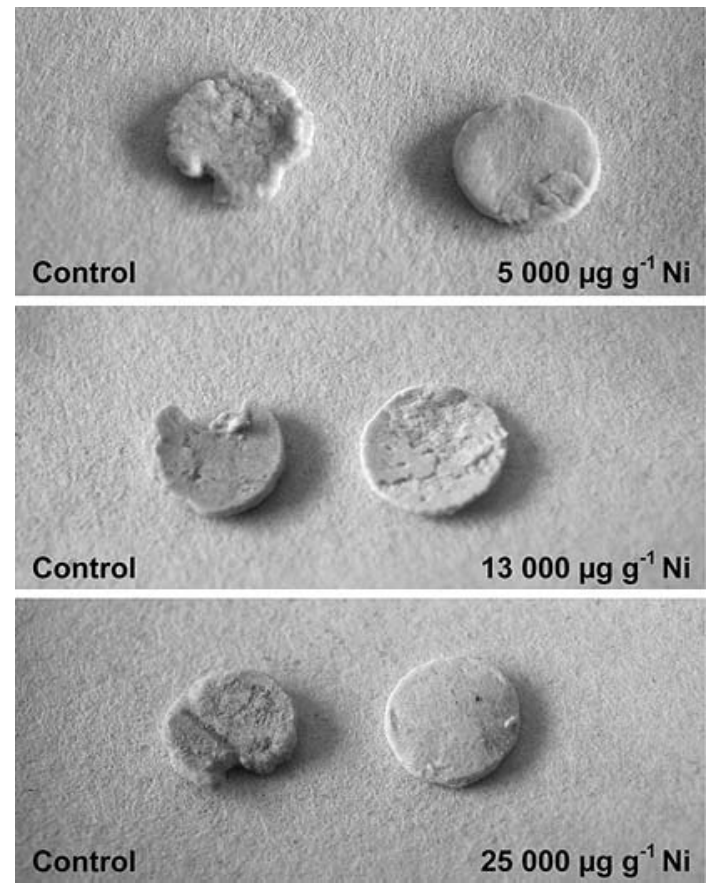

Fig. 4 Feeding damage by Tribolium castaneum when offered a choice between control disks and $\mathrm{Ni}$ amended disks in the following combinations: (control $+5,000 \mu \mathrm{g} \mathrm{g}^{-1} \mathrm{Ni}$ ), $\left(\right.$ control $\left.+13,000 \mu \mathrm{g} \mathrm{g}^{-1} \mathrm{Ni}\right)$ and (control $+25,000 \mu \mathrm{g} \mathrm{g}^{-1}$ $\mathrm{Ni})$; each disk $8 \mathrm{~mm} \varnothing$ are means \pm SE of four replicates per treatment with 10 insects per replicate. Food consumption in each combination was analysed using paired $t$-tests; ns, no significant feeding preference; *, significant preference at $P<0.05$

the experiment, isopods fed $A$. pintodasilvae litter suffered $83 \%$ mortality whereas isopods fed I. procumbens suffered only $8 \%$ mortality; isopods fed $M$. juliana and $A$. glutinosa had $100 \%$ survival. Survival of isopods fed A. pintodasilvae litter decreased over time (Fig. 5). Food consumption rate showed that isopods did not completely refuse $A$. pintodasilvae litter (Fig. 6a). Nevertheless, consumption rate of $A$. pintodasilvae litter was significantly lower than that of the other three plant species $\left(F_{3,43}=34.6\right.$, $P<0.001)$. Accordingly, at the end of the experiment, only isopods fed $A$. pintodasilvae litter lost biomass $\left(F_{3,33}=9.38, P<0.001\right.$; Fig. $\left.6 \mathrm{~b}\right)$; the two survivors registered a decrease in weight of $0.45 \pm 0.35 \mathrm{mg}$ (mean $\pm \mathrm{SE})$. Isopods fed I. procumbens experienced a weight increase of $10.6 \pm 1.07 \mathrm{mg} ;$ isopods fed $M$. juliana and A. glutinosa had mean weight increases of $7.80 \pm 0.97$ and $12.8 \pm 1.20 \mathrm{mg}$, respectively (Fig. 6b). Isopods fed A. pintodasilvae litter showed significantly lower growth efficiency than isopods fed $A$. glutinosa, $M$. juliana and I. procumbens litter $\left(F_{3,33}=8.17, \quad P<0.001\right.$; Fig. 6c). 
Fig. 5 Survival of Porcellio dilatatus fed with litter from Alyssum pintodasilvae, Iberis procumbens, Micromeria juliana and Alnus glutinosa during 30 days. Values are means of 12 replicates per treatment. On day 30 , means \pm SE are shown; *, significant difference at $P<0.05$ according to Tukey's posthoc test

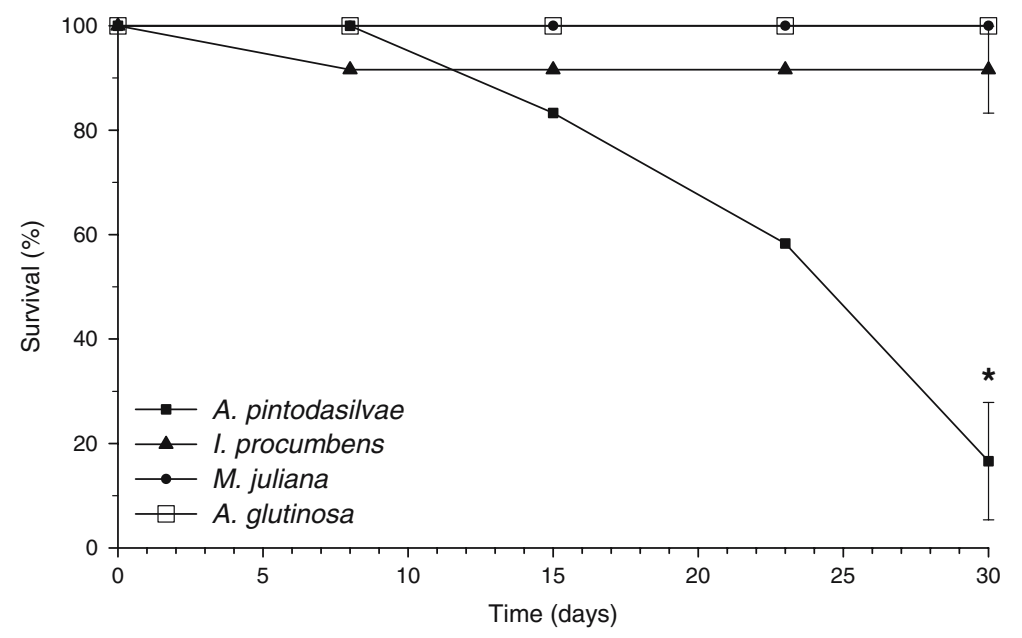

\section{Discussion}

In the first experiment, Tribolium castaneum was fed wheat flour amended with powdered Alyssum pintodasilvae leaves. The concentration of $\mathrm{Ni}$ in the composite leaf sample used in the experiment was $9,900 \mu \mathrm{g} \mathrm{g}^{-1} \mathrm{Ni}$, from which we could infer the following $\mathrm{Ni}$ concentrations in the leaf amended diets: 200,500 and $1,000 \mu \mathrm{g} \mathrm{g}^{-1}$. In the low and intermediate treatments, the concentrations of $\mathrm{Ni}$ were above the minimum concentration defining accumulation for $\mathrm{Ni}\left(100 \mu \mathrm{g} \mathrm{g}^{-1}\right)$, whereas the $1,000 \mu \mathrm{g} \mathrm{g}^{-1} \mathrm{Ni}$ treatment was at the lower limit for $\mathrm{Ni}$ hyperaccumulation (Reeves and Baker 2000). Recently, it has been suggested that metals could act as elemental defences at concentrations far below the values of hyperaccumulation (Hanson et al. 2004; Coleman et al. 2005) and account for the evolution of the hyperaccumulation trait (Boyd and Moar 1999; Boyd 2004). We did not observe a significant effect on reproduction nor on biomass change (Fig. 1) when T. castaneum was fed wheat flour amended with powdered leaves of $A$. pintodasilvae. Therefore, we found no evidences supporting the former hypothesis. The $1,000 \mu \mathrm{g} \mathrm{g}^{-1} \mathrm{Ni}$ treatment induced a decrease in insects' biomass which, although not statistically significant (Fig. 1c), may be a hint at defence.

The results from the experiments with artificial diet amended with $\mathrm{Ni}$ (no-choice and choice trials) suggest that high concentration of $\mathrm{Ni}$ deterred feeding by $T$. castaneum. When adult specimens were given access to single disks of artificial diet with increasing $\mathrm{Ni}$ concentrations (no-choice experiment), food consumption was significantly reduced (Fig. 2a). Moreover, even though insects were starved before the experiment, they refused to feed on diet disks with the highest Ni concentration $\left(25,000 \mu \mathrm{g} \mathrm{g}^{-1}\right)$. Results from this experiment showed a significant deterrence of herbivory even at the lowest level of $\mathrm{Ni}$ added: $5,000 \mu \mathrm{g} \mathrm{g}^{-1}$. If similar deterrence occurs under natural conditions, it could explain impacts by herbivores and their host preferences on A. pintodasilvae-dominated plant communities (Martens and Boyd 2002). However, Peterson et al. (2003) suggested that in Portuguese serpentine outcrops some herbivores (at least grasshoppers) might have coevolved with $A$. pintodasilvae since trophic transfer of $\mathrm{Ni}$ was evident. The results from the choice experiment agree with those from the no-choice experiment. When given a choice between control disks and $\mathrm{Ni}$ amended ones (in low, intermediate and high concentrations), insects clearly preferred control disks (Figs. 3, 4). The only exception was one replicate in the combination (control $+13,000 \mu \mathrm{g} \mathrm{g}^{-1}$ ) where insects did not discriminate between disks. In the combination (control $+25,000 \mu \mathrm{g} \mathrm{g}^{-1}$ ) insects completely refused to eat $\mathrm{Ni}$ amended disks although insects were starved before the experiment and one could expect this procedure to decrease food discrimination (Pollard and Baker 1997). Thus, our results support that $\mathrm{Ni}$ has an antifeedant effect. 

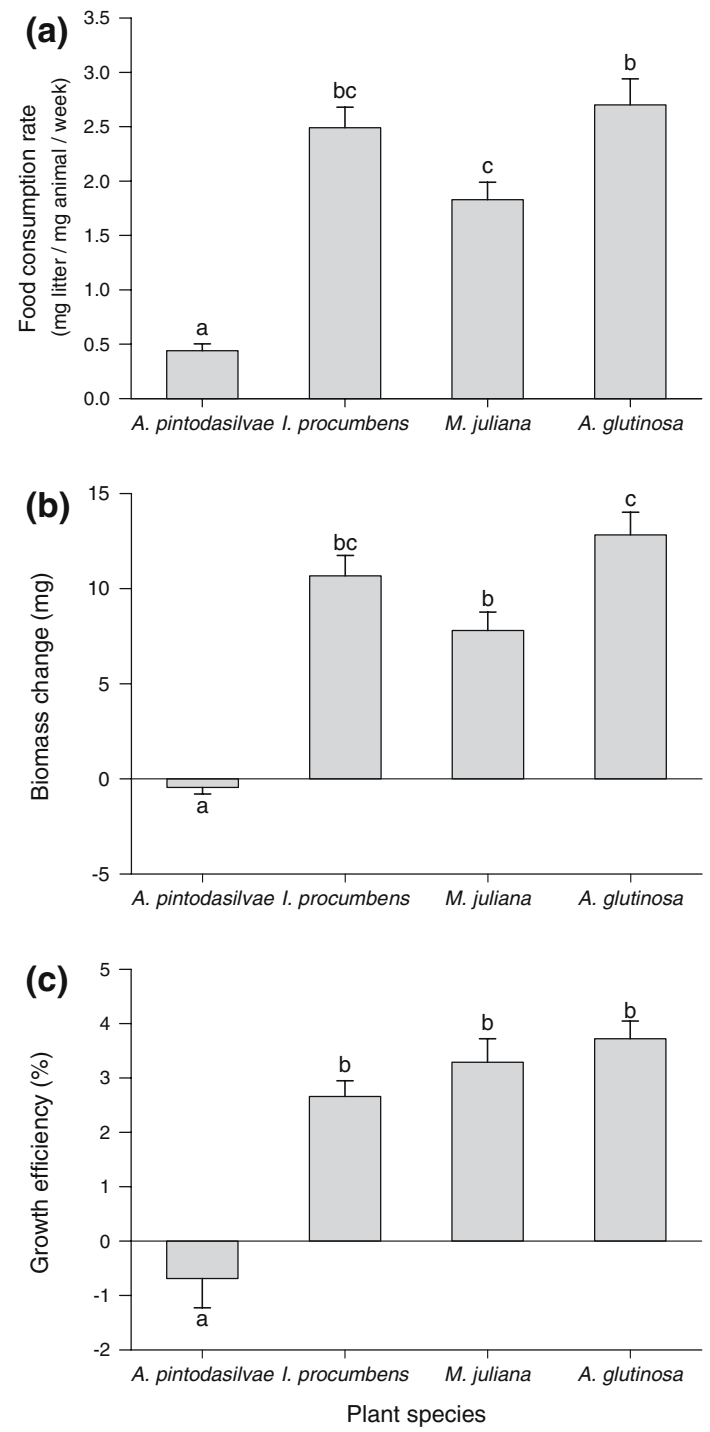

Fig. 6 (a) Food consumption rate of litter by Porcellio dilatatus along the experiment, (b) Biomass change and (c) Growth efficiency of $P$. dilatatus survivors after 30 days feeding litter from Alyssum pintodasilvae, Iberis procumbens, Micromeria juliana and Alnus glutinosa. Values are means \pm SE. Different letters indicate significant differences at $P<0.05$ according to Tukey's post-hoc test

Feeding deterrence has been demonstrated in Thlaspi caerulescens using both artificial diet and leaves of this hyperaccumulator species (Pollard and Baker 1997; Jhee et al. 1999; Behmer et al. 2005). Recently, Boyd and Jhee (2005) have shown that Ni can defend the hyperaccumulator Streptanthus polygaloides from slug herbivory via both acute toxicity and deterrence. In another $\mathrm{Ni}$ hyperaccumulator, Thlaspi montanum var. montanum, plant defence was by acute toxicity, since Pieris rapae larvae fed high-Ni leaves did not grow and suffered 100\% mortality (Boyd and Martens 1994). In our experiments with T. castaneum fed synthetic diet disks, feeding deterrence was evident but not acute toxicity, since mortality was not significantly different between $\mathrm{Ni}$ treatments in the no-choice experiment. In the choice experiment, although we did not detect consumption of high $\mathrm{Ni}$ disks in the combination (control $\left.+25,000 \mu \mathrm{g} \mathrm{g}^{-1}\right)$, the question remains if T. castaneum were able to taste $\mathrm{Ni}$.

Responses of Porcellio dilatatus fed A. pintodasilvae litter were markedly different from those fed with the other three plant species' litter. Isopods fed $A$. pintodasilvae litter suffered significantly greater mortality (Fig. 5). Moreover, in the $A$. pintodasilvae treatment isopods had the lowest litter consumption rate and, accordingly, the survivors showed the lowest growth efficiency and were the only ones to lose weight (Fig. 6). Could all these differences be attributed to differences in leaf Ni concentration? Litter characteristics were assessed through $\mathrm{Ni}$ and total phenolics quantification. The analyses showed that: (i) total phenolics were not significantly different among the four plant species, (ii) $\mathrm{Ni}$ detected in the litter of the non-hyperaccumulator species was in the normal range and (iii) $\mathrm{Ni}$ concentration in $A$. pintodasilvae did not decrease after leaf conditioning. Results suggest an antifeedant effect of $A$. pintodasilvae litter caused by the high Ni concentration. Feeding deterrence of A. pintodasilvae litter was suggested by much smaller food consumption in comparison with the other three leaf types. However, acute toxic effects of $\mathrm{Ni}$ were possible because a small amount of litter was consumed in all $A$. pintodasilvae treatment replicates. Furthermore, we do not know how long isopods would have survived if kept under starvation. This kind of control treatment was included by Boyd and Jhee (2005) in their experiments and allowed them to demonstrate an acute toxic effect of high-Ni $S$. polygaloides since slugs offered these plants had a significantly greater mortality than slugs that were not fed. The much lower amount of A. pintodasilvae litter eaten in comparison with 
the other three plant species could be explained by toxic effects of $\mathrm{Ni}$ during post-ingestive mechanisms in such a way that small quantities of $\mathrm{Ni}$ are enough to cause toxicity (Behmer et al. 2005). This might account for the significant great mortality of isopods fed A. pintodasilvae litter, especially evident in the second half of the experiment (Fig. 5). In the context of ecotoxicological studies, Porcellio scaber was shown to be able to discriminate against food contaminated with metals $(\mathrm{Cu}, \mathrm{Cd})$. However, deterrence probably depends on previous experience with contaminated food and/or high metal body load. Selection of food is probably based on taste or adverse metabolic effects of ingested metal (Zidar et al. 2004; Zidar et al. 2005). Using our experimental approach, quantification of $\mathrm{Ni}$ in isopod bodies at the end of the experiment could allow discriminating between deterrent and toxic $\mathrm{Ni}$ effects (Hanson et al. 2003; Raessler et al. 2005). Also, performing choice experiments and repeating the no-choice trial but including a starvation control could help sorting out the mechanisms beneath $P$. dilatatus response (Behmer et al. 2005). In turn, the use of congeneric non-hyperaccumulator species of Alyssum or of low- and high-Ni A. pintodasilvae leaves (by growing $A$. pintodasilvae on both high- and low$\mathrm{Ni}$ soils), would allow focusing on $\mathrm{Ni}$ as the key feature affecting isopods performance (Boyd and Jhee 2005; Jhee et al. 2006).

Whatever the mechanisms involved, and in spite of differences unaccounted for between leaf types in our experiment, results suggest that $\mathrm{Ni}$ concentration in A. pintodasilvae litter might pose a general problem to isopods. Consequences are likely to be two-fold: first, if detritivore activity is prevented in natural conditions we may expect a slower rate of decomposition of $A$. pintodasilvae litter. Secondly, we might expect metal tolerant isopods to evolve in these habitat niches (Boyd and Martens 1998; Pollard 2000; Boyd 2004).

In conclusion, we provide evidence that high $\mathrm{Ni}$ concentration in leaves of $A$. pintodasilvae acts as elemental defence against herbivores in agreement with previous studies on Ni hyperaccumulation (Boyd and Martens 1994; Martens and Boyd 1994; Boyd et al. 2002; Boyd and Jhee 2005; Jhee et al. 2006). Our results, though, further suggest the defence hypothesis is valid towards detritivores. This is one of the few studies attempting to unravel the consequences of plant metal hyperaccumulation for the ecosystem processes of decomposition (Boyd and Martens 1998; Boyd 2004). The only other study focusing on this issue is the recent work by Zhang et al. (2005), in which the authors investigated the degradation of Alyssum murale biomass in soil. In our experiments, deterrence of herbivory arose as the most probable mechanism to explain how $\mathrm{Ni}$ defends A. pintodasilvae from herbivores but toxic effects could not be ruled out. The clarification of this point awaits further investigation.

Acknowledgments We thank two anonymous reviewers for their valuable insights and comments on the manuscript.

\section{References}

Alonso-Amelot ME, Avila JL, Otero LD, Mora F, Wolff B (1994) A new bioassay for testing-plant extracts and pure compounds using red flour beetle Tribolium castaneum Herbst. J Chem Ecol 20:1161-1177

Behmer ST, Lloyd CM, Raubenheimer D, Stewart-Clark J, Knight J, Leighton RS, Harper FA, Smith JAC (2005) Metal hyperaccumulation in plants: mechanisms of defence against insect herbivores. Funct Ecol 19:5566

Boyd RS (2004) Ecology of metal hyperaccumulation. New Phytol 162:563-567

Boyd RS, Davis MA, Wall MA, Balkwill K (2002) Nickel defends the South African hyperaccumulator Senecio coronatus (Asteraceae) against Helix aspersa (Mollusca: Pulmonidae). Chemoecology 12:91-97

Boyd RS, Jhee EM (2005) A test of elemental defence against slugs by $\mathrm{Ni}$ in hyperaccumulator and nonhyperaccumulator Streptanthus species. Chemoecology 15:179-185

Boyd RS, Martens SN (1994) Nickel hyperaccumulated by Thlaspi montanum var montanum is acutely toxic to an insect herbivore. Oikos 70:21-25

Boyd RS, Martens SN (1992) The raison d'être for metal hyperaccumulation by plants. In: Baker AJM, Proctor J, Reeves RD (eds) The vegetation of ultramafic (serpentine) soils. Intercept Ltd, Andover, pp 279-289

Boyd RS, Martens SN (1998) The significance of metal hyperaccumulation for biotic interactions. Chemoecology 8:1-7

Boyd RS, Moar WJ (1999) The defensive function of Ni in plants: response of the polyphagous herbivore Spodoptera exigua (Lepidoptera: Noctuidae) to hyperaccumulator and accumulator species of Streptanthus (Brassicaceae). Oecologia 118:218-224 
Boyd RS, Shaw JJ, Martens SN (1994) Nickel hyperaccumulation defends Streptanthus polygaloides (Brassicaceae) against pathogens. Am J Bot 81:294-300

Brooks RR, Lee J, Reeves RD, Jaffré T (1977) Detection of nickeliferous rocks by analysis of herbarium specimens of indicator plants. J Geochem Explor 7:49-57

Brooks RR, Radford CC (1978) Nickel accumulation by European species of genus Alyssum. P Roy Soc Lond B Bio 200:217-224

Caseiro I, Santos S, Sousa JP, Nogueira AJA, Soares AMVM (2000) Optimization of culture conditions of Porcellio dilatatus (Crustacea: Isopoda) for laboratory test development. Ecotox Environ Safe 47:285-291

Coleman CM, Boyd RS, Eubanks MD (2005) Extending the elemental defence hypothesis: dietary metal concentrations below hyperaccumulator levels could harm herbivores. J Chem Ecol 31:1669-1681

Dudley TR (1986) A new nickelophilous species of Alyssum (Cruciferae) from Portugal, Alyssum pintodasilvae T. R. Dudley. Feddes Repert 97:135-138

Ghaderian YSM, Lyon AJE, Baker AJM (2000) Seedling mortality of metal hyperaccumulator plants resulting from damping off by Pythium spp. New Phytol 146:219-224

Hanson B, Garifullina GF, Lindblom SD, Wangeline A, Ackley A, Kramer K, Norton A P, Lawrence CB, Pilon-Smits EAH (2003) Selenium accumulation protects Brassica juncea from invertebrate herbivory and fungal infection. New Phytol 159:461-469

Hanson B, Lindblom SD, Loeffler ML, Pilon-Smits EAH (2004) Selenium protects plants from phloem-feeding aphids due to both deterrence and toxicity. New Phytol 162:655-662

Huitson SB, Macnair MR (2003) Does zinc protect the zinc hyperaccumulator Arabidopsis halleri from herbivory by snails? New Phytol. 159:453-459

Jhee EM, Boyd RS, Eubanks MD, Davis MA (2006) Nickel hyperaccumulation by Streptanthus polygaloides protects against the folivore Plutella xylostella (Lepidoptera : Plutellidae). Plant Ecol 183:91-104

Jhee EM, Dandridge KL, Christy AM, Pollard AJ (1999) Selective herbivory on low-zinc phenotypes of the hyperaccumulator Thlaspi caerulescens (Brassicaceae). Chemoecology 9:93-95

Jiang RF, Ma DY, Zhao FJ, McGrath SP (2005) Cadmium hyperaccumulation protects Thlaspi caerulescens from leaf feeding damage by thrips (Frankliniella occidentalis). New Phytol 167:805-813

Martens SN, Boyd RS (2002) The defensive role of Ni hyperaccumulation by plants: a field experiment. Am J Bot 89:998-1003

Martens SN, Boyd RS (1994) The ecological significance of nickel hyperaccumulation - a plant-chemical defense. Oecologia 98:379-384

Menezes de Sequeira E, Pinto da Silva A R (1992) The ecology of serpentinized areas of north-east Portugal. In: Roberts BA, Proctor J (eds) The ecology of areas with serpentinized rocks. A world view. Kluwer Academic Publishers, Dordrecht, pp 169-197

Noret N, Meerts P, Tolrà R, Poschenrieder C, Barceló J, Escarre J (2005) Palatability of Thlaspi caerulescens for snails: influence of zinc and glucosinolates. New Phytol 165:763-772

Ó Ceallacháin DP, Ryan MF (1977) Production and perception of pheromones by beetle Tribolium confusum. J Insect Physiol 23:1303-1309

Peterson LR, Trivett V, Baker AJM, Aguiar C, Pollard AJ (2003) Spread of metals through an invertebrate food chain as influenced by a plant that hyperaccumulates nickel. Chemoecology 13:103-108

Pinto da Silva AR (1970) A flora e a vegetação das áreas ultrabásicas do nordeste transmontano. Agronomia Lusit 30:175-364

Pollard AJ (2000) Metal hyperaccumulation: a model system for coevolutionary studies. New Phytol 146:179-181

Pollard AJ, Baker AJM (1997) Deterrence of herbivory by zinc hyperaccumulation in Thlaspi caerulescens (Brassicaceae). New Phytol 135:655-658

Raessler M, Rothe J, Hilke I (2005) Accurate determination of $\mathrm{Cd}, \mathrm{Cr}, \mathrm{Cu}$ and $\mathrm{Ni}$ in woodlice and their skins is moulting a means of detoxification? Sci Total Environ 337:83-90

Reeves RD, Baker AJM (2000) Metal-accumulating plants. In: Raskin I, Ensley BD (eds) Phytoremediation of toxic metals: using plants to clean up the environment. John Wiley \& Sons, New York, pp 193-229

Ribeiro S, Guilhermino L, Sousa JP, Soares AMVM (1999) A novel bioassay based on acetylcholinesterase and lactate dehydrogenase activities to evaluate the toxicity of chemicals to soil isopods. Ecotox Environ Safe 44:287-293

Ribeiro S, Sousa JP, Nogueira AJA, Soares AMVM (2001) Effect of endosulfan and parathion on energy reserves and physiological parameters of the terrestrial isopod Porcellio dilatatus. Ecotox Environ Safe 49:131-138

Sousa JP, Vingada JV, Loureiro S, Gama MM, Soares AMVM (1998) Effects of introduced exotic tree species on growth, consumption and assimilation rates of the soil detritivore Porcellio dilatatus (Crustacea: Isopoda). Appl Soil Ecol 9:399-403

SPSS 2005 SPSS for Windows, Release 14.0, Chicago, IL, USA

Swain T, Hillis WE (1959) The phenolic constituents of Prunus domestica. I. The quantitative analysis of phenolic constituents. J Sci Food Agr 10:63-68

Szlávecz K, Pobozsny M (1995) Coprophagy in isopods and diplopods: a case for indirect intercation. Acta Zool Fennica 196:124-128

Van Wensem J, Verhoef HA, Van Straalen NM (1993) Litter degradation stage as a prime factor for isopod interaction with mineralization processes. Soil Biol Biochem 25:1175-1183

Whiting SN, Neumann PM, Baker AJM (2003) Nickel and zinc hyperaccumulation by Alyssum murale and Thlaspi caerulescens (Brassicaceae) do not enhance 
survival and whole-plant growth under drought stress. Plant Cell Environ 6:351-360

Zar JH (1996) Biostatistical Analysis. Prentice Hall International, Upper Saddle River, 662 pp

Zhang L, Angle JS, Delorme T, Chaney RL (2005) Degradation of Alyssum murale biomass in soil. Int J Phytorem 7:169-176

Zidar P, Bozic J, Strus J (2005) Behavioral response in the terrestrial isopod Porcellio scaber (Crustacea) offered a choice of uncontaminated and cadmium-contaminated food. Ecotoxicology 14:493-502

Zidar P, Drobne D, Strus J, Van Gestel CAM, Donker M (2004) Food selection as a means of $\mathrm{Cu}$ intake reduction in the terrestrial isopod Porcellio scaber (Crustacea, Isopoda). Appl Soil Ecol 25:257-265 